\title{
ПОНЯТТЯ ТА СУТНІСТЬ НОРМОТВОРЧОЇ ДІЯЛЬНОСТІ ЦЕНТРАЛЬНИХ ОРГАНІВ ВИКОНАВЧОЇ ВЛАДИ
}

\begin{abstract}
Постановка проблеми. Від якості підзаконних нормативно-правових актів цілком і повністю залежить якість правового регулювання суспільних відносин у країні, захист інтересів, прав та свобод громадян. Проблема низької ефективності та якості нормотворчої діяльності центральних органів виконавчої влади є не тільки очевидною, але й потребує негайного вирішення, оскільки вона гальмує подальший процес становлення в Україні дієвої системи регулювання суспільних відносин. Проте не можна категорично стверджувати, що в Україні сьогодні нормотворчий процес центральних органів виконавчої зовсім не врегульовано. Утім, регулювання такого важливого питання, як нормотворча діяльність центральних органів виконавчої влади, яка складає базисну основу розвитку та реалізації законодавства, залишається на рівні підзаконних нормативно-правових актів, які не завжди одноманітно та в єдиному руслі врегульовують відповідні відносини. Навпаки, наявні суперечності та прогалини. Саме тому у процесі дослідження неодноразово наголошується на необхідності прийняття Закону України «Про правотворчу діяльність та нормативно-правові акти», яким будуть врегульовані питання нормотворчої діяльності взагалі та центральних органів виконавчої зокрема, а також нормативно-правових актів як результату нормотворчої діяльності. Усе це дозволяє зробити висновок про те, що дослідження проблемних питань
\end{abstract}

правового регулювання нормотворчої діяльності центральних органів виконавчої, їх оптимального функціонування на сучасному етапі суспільного розвитку набуває особливої гостроти і актуальності.

Аналіз останніх досліджень i публікацій. Проблеми поняття та змісту нормотворчої діяльності центральних органів виконавчої влади розглядалися в роботах представників вітчизняної і зарубіжної юридичної науки різних історичних періодів у галузі адміністративного та конституційного права, теорії держави та права, серед яких слід відзначити праці В.Б. Авер'янова, С.С. Алексєєва, О.Ф. Андрійко, Г.В. Атаманчука, О.М. Бандурки, Д.М. Бахраха, Ю.П. Битяка, С.Н. Братуся, М.М. Бурбики, Л.К. Воронової, B.M. Гаращука, В.K. Гіжевського, I.П. Голосніченка, І.С. Гриценка, С.М. Гусарова, Є.В. Додіна, В.В. Зуй, P.A. Калюжного, С.В. Ківалова, В.В. Конопльова, В.В. Копєйчикова, В.О. Котюка, Є.В. Курінного, B.M. Марчука, О.М. Музичука, В.Я. Настюка, Л.В. Ніколаєву, Н.Р. Нижник, В.І. Олефіра, О.В. Петришина, В.П. Пєткова, В.М. Поповича, Н.Ю. Пришви, П.М. Рабіновича, О.Ф. Скакун, С.Г. Стеценка, В.П. Чабана, В.О. Шамрая, В.M. Шаповала, О.О. Шевченка, Ю.С. Шемшученка, I.M. Шопіної та інших. Однак, незважаючи на значну кількість наукових праць, опублікованих останніми роками, необхідність вирішення проблем правового 


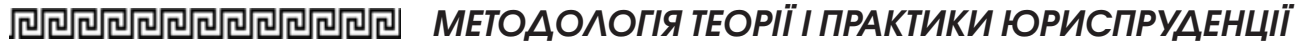

регулювання нормотворчої діяльності центральних органів виконавчої влади, з одного боку, та відсутність комплексних наукових досліджень із цієї проблематики - з іншого, зумовлюють актуальність та важливість наукового дослідження із зазначеного питання в умовах проведення адміністративної реформи.

Формування цілей. Мета статті полягає в тому, щоб на основі аналізу наявних наукових підходів, а також чинного законодавства України і узагальнення практики його реалізації визначити сутність та особливості правового регулювання нормотворчої діяльності органів виконавчої влади в умовах їх реформування, а також окреслити шляхи його вдосконалення.

Виклад основного матеріалу. Нормотворча діяльність центральних органів виконавчої влади, іiі поняття, зміст, правове регулювання є однією з актуальних проблем в Україні, яка, попри досить великий обсяг теоретичних досліджень, залишає відкритим питання законодавчої регламентації та практичної реалізації нормотворчого процесу взагалі та органів виконавчої влади зокрема. Саме нормотворча діяльність займає одне з важливих місць у системі факторів, від яких залежать позитивні результати формування правової системи країни в умовах проведення правової реформи, результати нормотворчої діяльності відображають загальне враження про правову систему держави, ступінь ї демократичності, розвитку, цивілізованості.

Сьогодні для визначення процесу формування (створення) норм права, нормативно-правових актів, законодавства та права в цілому застосовуються поняття правотворчості, нормотворчості та законотворчості. Разом із тим ані законодавець, ані теоретики-науковці не дійшли єдиного, загальноприйнятного визначення цих понять, їх взаємозв'язків. Так, в Юридичній енциклопедії Ю.С. Шемшученко під поняттям правотворчості пропонує розуміти «напрям діяльності держави, пов'язаний з офіційним закріпленням норм права шляхом формування приписів, їх зміни, доповнення та скасування ..., спрямована на створення та вдосконалення єдиної, внутрішньо узгодженої системи норм, що регулюють суспільні відносини» та визначення нормотворчості відсилає до поняття правотворчості. Тобто зазначені поняття, на думку Ю.С. Шемшученка, $€$ ідентичними [1, с. 643]. У Сучасній правовій енциклопедії під правотворчістю мається на увазі «форма владної діяльності держави, спрямована на створення нормативно-правових актів, за допомогою яких в чинній юридичній системі запроваджуються, змінюються чи скасовуються правові норми [2, c. 269].

А.О. Расюк визначає нормотворчість як діяльність уповноважених на це суб'єктів 3 розроблення, розгляду, прийняття та офіційного оприлюднення нормативно-правових актів, яка здійснюється за визначеною процедурою [3, с. 142]. С. Чабур зазначає, що правотворчість є однією з важливих правових форм поряд із засновницькою, правозастосовною та контрольно-наглядовою діяльність держави, шляхом реалізаціі яких вона і здійснює свої функціï. Правотворчість, на його думку, $€$ «діяльністю компетентних органів держави, посадових осіб, спеціально уповноважених громадських організацій, трудових колективів або всього населення із встановлення, зміни, відміни та систематизації юридичних норм» [4, с. 114]. T.I. Тарахонич під правотворчістю розуміє «особливу форму діяльності державних органів 3 розробки i прийняття нормативно-правових актів 3 метою встановлення, зміни або відміни юридичних норм» [5, с. 62]. Р.И. Наджафгулиев зазначає, що правотворчість є процесом втілення волі держави в законі, оформлення іï в певних нормативно-правових актах, надання правилам 
поведінки загальнообов'язкового характеру [6, с. 40]. Ю.В. Шапран вважає, що правотворчість та нормотворчість $є$ ідентичними поняттями та розуміє під ними діяльність держави із втілення у формі закону державної волі. Він наголошує, що правотворчий процес - це послідовні організаційні дії, які й складаЮть зміст нормотворчості [7, с. 267]. В.В. Жидецька, у свою чергу, додає, що процес нормотворчості є складним соціальним процесом, який «поєднує дію нормативно-правових актів об'єктивної дійсності та суб'єктивну думку нормотворчого органу» та вважає, що «основою ефективного законодавства, основним показником» реальної дії норм права буде лише «розробка об'єктивно обумовлених нормативно-правових актів, які відображають суспільні потреби» [8, с. 50].

Таким чином, вбачається, що одні науковці під час дослідження зазначеного питання застосовують поняття правотворення, інші - нормотворення, але всі вони в ці поняття закладають однаковий зміст. Діяльність щодо створення (зміни, відміни, доповнення) норми права є діяльністю зі створення і системи права, і системи законодавства та, відповідно, може бути визначена і правотворенням, і нормотворенням.

Тобто поняття правотворення $є$ більш узагальнюючим відносно нормотворення, під яким треба розуміти діяльність усіх уповноважених органів із формування права. Ураховуючи, що результатами діяльності органів виконавчої влади зі створення нормативно-правових актів є підзаконні нормативно-правові акти, вважаємо за доцільне відносно цієї діяльності використовувати термін «нормотворча діяльність», що має більшою мірою відображати зміст цього виду процесуальної діяльності системи органів виконавчої влади в Україні. Це підтверджується також нормами Положення про державну реєстрацію нормативно-правових актів міністерств, інших органів виконавчої влади, яким визначено, що суб'єктами нормотворення $€$ міністерства та інші органи виконавчої влади.

Важливе значення під час розмежуванні понять правотворчість, законотворчість та нормотворчість має визначення суб'єктного складу кожного з процесів. Так, М.В. Левченко суб'єктами правотворчості визначає державні органи, недержавні структури, наділені відповідними повноваженнями, до яких він відносить органи місцевого самоврядування, профспілки тощо, а також громадян, за умови проведення референдумів [9, с. 50]. I.O. Чаплюк вважає, що суб'єктами правотворчості є: державні органи; громадські організаціі; трудові колективи; населення держави при проведенні референдумів, а також можуть бути органи місцевого самоврядування та адміністрації підприємств та установ [10, с. 36]. С.В. Чабур зазначає, що правотворчість здійснюється державою (іï органами та посадовими особами) і «громадянським суспільством та його суб'єктами» [11, с. 34].

Таким чином, убачається, що коло суб'єктів правотворчості дійсно набагато ширше, ніж суб'єктів нормотворення, що й підтверджує нашу позицію відносно того, що правотворення $€$ більш узагальненим, широким поняттям, ніж нормотворення, коло суб'єктів якого обмежується органами виконавчої влади різних рівнів.

Правотворча діяльність відрізняється від інших видів державної (санкціонованої) діяльності певними специфічними ознаками. Науковці виділяють такі ознаки правотворчості: здійснюється державою (безпосередньо або з іiі дозволу), а також народом; виявляється у створенні, зміні чи скасуванні норм права; реалізується в нормативно-правовому акті; здійснюється відповідно до встановленої процедури; має конкретно-цільову і організаційну спрямованість. Правотворчість є активною, 


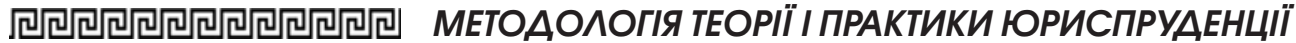

творчою державною діяльністю; основним результатом правотворчості є юридичні норми, втілені в нормативно-правових актах; $€$ засобом управління суспільством, бо саме в нормативних актах закріплюються правила поведінки; якість нормативних актів є основним показником цивілізованості та демократії в державі. На думку А.М. Ващенко, правотворчість характеризується такими ознаками: по-перше, правотворчість $€$ «юрисдикційною діяльністю держави (або) уповноваженого органу, організації; по-друге, «має об'єктивну спрямованість»; по-третє, «відображається в актах, що містять норми права чи скасовують, змінюють їх; по-четверте, «суворо регламентується правовими нормами» [12, с. 136].

Вищевизначені ознаки $є$ специфічними характерними особливостями правотворчості, однак ми вважаємо, що нормотворчість як вид спеціальної діяльності системи органів виконавчої влади має свої, притаманні їй ознаки, які відображають їі специфіку та відрізняють від інших видів діяльності. Так, основними ознаками нормотворчості органів виконавчої влади, на нашу думку, є державна діяльність: яка реалізується через систему органів виконавчої влади; яка здійснюється в порядку і процедурі, які регламентовані чинним законодавством; результатом якої $€$ нові чи вдосконалені підзаконні нормативно-правові акти.

Особливе місце та роль у нормотворчому процесі в Україні, на нашу думку, відіграє Міністерство юстиції та система органів юстиції. Перш за все, Указом Президента України «Про заходи щодо вдосконалення нормотворчої діяльності органів виконавчої влади» саме на Міністерство юстиції України покладено функції 3 «планування законопроектної роботи ... координації нормотворчої діяльності органів виконавчої влади та контролю за цією діяльністю» [13]. Саме Міністерство юстиціï України та система його органів здійснює правову експертизу нормативно-правових актів та подальшу їх державну реєстрацію, вони є одним із засобів контролю та впливу держави на нормотворчу діяльність суб'єктів нормотворення. «3 метою забезпечення єдиних принципів у нормотворчій роботі Міністерство юстиції надає центральним органам виконавчої влади методичну допомогу у сфері нормопроектування». На базі Центру перепідготовки та підвищення кваліфікації працівників юстиції постійно здійснюються заходи щодо навчання працівників юридичних служб міністерств та центральних органів виконавчої влади, до повноважень яких входить розробка проектів нормативно-правових актів.

Отже, аналіз Положення про Міністерство юстиції України дозволив визначити основні функції, які покладені на Міністерство юстиції під час реалізації нормотворчого процесу в Україні: «розробляє за дорученням Президента України, Кабінету Міністрів України та 3 власної ініціативи проекти законів та інших нормативно-правових актів»; «розробляє пропозиції щодо вдосконалення законодавства та подає їх у встановленому порядку на розгляд Кабінету Міністрів України»; «здійснює правову експертизу проектів ... актів законодавства, які подаються на розгляд Кабінету Міністрів України»; проводить антикорупційну та гендерно-правову експертизу нормативно-правових актів; «здійснює державну реєстрацію нормативно-правових актів міністерств, інших центральних органів виконавчої влади, а також інших органів, акти яких відповідно до законодавства підлягають державній реєстрації»; «розробляє за пропозиціями міністерств та інших центральних органів виконавчої влади плани законопроектної роботи, координує нормотворчу діяльність у міністерствах та інших центральних органах виконавчої влади, здійснює контроль за такою діяльністю»; забезпечує ведення Єдиного державного реєстру нормативно-правових актів; «здійснює офіційне 
опублікування нормативно-правових актів...».

Таким чином, можна дійти висновку, що Міністерство юстиції України та система його органів є обов'язковим універсальним суб'єктом нормотворчого процесу в Україні.

Із метою систематизації та узагальнення наявних наукових доробок щодо нормотворчості деякі науковці пропонують класифікувати іiі за певними підставами. Так, правотворчість, на думку Т.О. Рябченко, може бути класифікована залежно від суб'єкта на правотворчість держави (ii органів та посадових осіб) і правотворчість громадянського суспільства (його суб’єктів). За силою юридичних актів правотворчість держави може бути розділена на законодавчу діяльність (прийняття законодавчих актів) і підзаконну правотворчу діяльність (прийняття підзаконних нормативно-правових актів). За «формою участі держави» правотворчу діяльність пропонується класифікувати на безпосередню правотворчість (полягає у виданні нормативно-правових актів державними органами та уповноваженими державною органами); санкціоновану правотворчість (полягає в попередньому дозволі або санкціонуванні видання нормативно-правових актів); спільну правотворчість (полягає в погодженні нормативних актів); делеговану правотворчість (розуміє передачу, делегування повноважень 3 правотворення органам державної влади нижчого рівня) [14, с. 8]. Ю. Лепех також пропонує класифікувати правотворчість залежно від участі держави в правотворчому процесі та виділяє такі види: безпосередню правоустановчу діяльність державних органів; делегування правотворчих повноважень недержавним організаціям; державне санкціонування певних норм, які склалися у суспільстві [15, c. 226].

Зрозуміло, що нормотворчість $€$ одним із важливих, необхідних видів діяльності держави, яка виявляється у формуванні (зміні, відміні, доповненні) норм права. Але в кожній державі нормотворчість наділена своїми особливостями, зумовленими певними факторами, та, разом із тим, у будьякій державі нормотворча діяльність спрямована на «створення та удосконалення єдиної, внутрішньоузгодженої ... системи норм, яка регулює різноманітні правовідносини, які складаються у суспільстві» [16, с. 47].

Тобто через процес нормотворчості нормативно регулюються абсолютно всі суспільні, правові, організаційні, фінансові та інші відносини в державі. Саме тому процес нормотворення потребує досконалого нормативно-правового регулювання, оскільки він і процес його створення є основою законодавчої, нормативної стабільності держави. Слід зазначити, що в більшості країн пострадянського простору нормотворча діяльність вже досить тривалий час врегульована на законодавчому рівні. Ураховуючи, що в Україні процес законодавчого регулювання нормотворчого процесу перебуває на підготовчому етапі, вважаємо за доцільне ознайомитися з досвідом іноземних країн, які вже позитивно вирішили це питання.

На нашу думку, не варто занадто «роздувати» законодавство України створенням великої кількості нормативно-правових актів, в тому числі законів. Так, ми вважаємо доцільним прийняття одного Закону України «Про правотворчу діяльність та нормативно-правові акти», лише таким чином в одному нормативно-правовому акті будуть об'єднані норми і матеріального (стосовно нормативно-правових актів, їх видів, системи, структури тощо), і процесуального (діяльність уповноважених органів щодо створення нормативно-правових актів, порядок їх створення залежно від органу та виду нормативно-правового акта) права. Разом із тим, ураховуючи досвід іноземних держав із законодавчого регулювання діяльності уповноважених органів із 


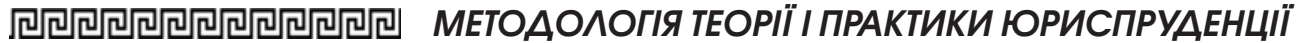

правотворчої діяльності, пропонуємо максимально конкретизовано викладати норми в цьому законі, та в обов'язковому порядку закон має містити перелік понять, які використовуватимуться в законі, перелік суб'єктів, які мають право брати участь у правотворчому процесі (органи, посадові особи, уповноважені на прийняття (видання) нормативно-правових актів; інші органи, установи, посадові особи, недержавні юридичні та фізичні особи, які можуть брати участь у процесі створення нормативно-правових актів як експерти, спеціалісти тощо), окремо визначити види правотворчого процесу: законотворчий (діяльність уповноважених органів зі створення нормативно-правових актів вищої юридичної сили кодексів, законів) та нормотворчий (діяльність органів виконавчої влади різних видів і рівнів зі створення підзаконних нормативно-правових актів - постанов, наказів та ін.).

Висновки. Таким чином, центральні органи виконавчої влади в Україні займають особливе місце в системі органів публічної влади як такі, що виконують повноваження виконавчо-розпорядчого, організуючого підзаконного характеру, їх значення полягає саме в забезпеченні повсякденного життя країни та суспільства шляхом реалізації управлінської діяльності. Водночас кожний центральний орган виконавчої влади як частина системи органів виконавчої влади може діяти ефективно, досконало реалізовувати владні повноваження лише за умови находження в системі. Функції центральних органів виконавчої влади мають особливе значення для встановлення закономірностей побудови i функціонування та визначення перспектив розвитку виконавчої влади та системи ї̈ органів.

Нормотворча діяльність центральних органів виконавчої влади становить сутність і зміст нормотворчого процесу, який $€$ різновидом право- творчості й полягає в діяльності уповноважених органів (державної виконавчої влади України та їх посадових осіб) зі створення нормативно-правових актів у порядку, суворо регламентованому законодавством (залежно від органу нормотворення та виду нормативно-правового акта, який створюється). Основними ознаками нормотворчої діяльності центральних органів виконавчої влади $€$ державна діяльність, яка: реалізується через систему органів виконавчої влади; здійснюється в порядку і за процедурою, що регламентовані чинним законодавством; результатом якої $€$ нові чи вдосконалені підзаконні нормативно-правові акти. Діяльність центральних органів виконавчої влади зі створення норм права може бути розділена на дві групи: основна (діяльність зі створення особистих нормативно-правових актів - нормотворча діяльність) та додаткова (участь у реалізації нормотворчої діяльності уряду - розробка проектів постанов).

У статті досліджені адміністративно-правові аспекти нормотворчої діяльності центральних органів виконавчої влади. Зазначено, що нормотворча діяльність иентральних органів виконавчої влади складає сутність $i$ зміст нормотворчого процесу, якии $е$ різновидом правотворчості $i$ полягає в діяльності уповноважених органів зі створення нормативно-правових актів у порядку, суворо регламентованому законодавством. Висловлено думку, що коло суб'єктів правотворчості набагато ширше, ніж суб’єктів нормотворення, що й підтверджує позицію відносно того, щзо правотворення є більи узагальненим, широким поняттям, ніж нормотворення, коло суб'єктів якого обмежується иентральними органами виконавчої влади. До характерних ознак актів иентральних органів виконавчої влади віднесено такі: це правила поведінки центральних 
органів виконавчої влади; ия поведінка спрямована на виконання нормативних приписів; виражається в певному правовому документі; видання таких актів здійснюеться у прочесі публічного управління; вони видаються уповноваженими на те державними органами чи їх посадовими особами; спрямованість їхньої дї може бути як загальною, так і індивідуальною; вони містять норми правової спрямованості; вони спрямовані на досягнення конкретно визначеного результату. Запропоновано класифікацію видів нормотворчої діяльності иентральних органів виконавчої влади за такими критеріями: залежно від рівня суб'єкта нормотворення; залежно від виду нормативно-правового акта, який створюється (класичний нормотворчий проиес та додатково-умовний нормотворчий процеес). Визначаються фактори, які зумовлюють необхідність реформування нормотворчої діяльності иентральних органів виконавчої влади Україні. Проводиться співвідношення правотворчої та нормотворчої діяльності центральних органів виконавчої влади. Виділяються блоки нормотворчого процесу изентральних органів виконавчої влади.

Характеризується Концепиія адміністративної реформи в Украіні як основа реформування нормотворчої иентральних діяльності органів виконавчої влади в Україні. 3'ясовані ознаки та види підзаконних нормативно-правових актів центральних органів виконавчої влади. Надані пропозичіi та рекомендації щодо удосконалення правового регулювання нормотворчої діяльності иентральних органів виконавчої влади.

Ключові слова: виконавча влада, міністерство, нормативно-правовий акт, нормотворча діяльність, повноваження, правове регулювання, публічне управління, центральний орган виконавчої влади
Baranenko D. Concept and essence of rule-making activity of central executive bodies

The article examines the administrative and legal aspects of rule-making activities of central executive bodies. It is noted that the rule-making activity of central executive bodies is the essence and content of the rule-making process, which is a kind of law-making and consists in the activities of authorized bodies to create regulations in the manner strictly regulated by law. The opinion is expressed that the circle of law-making subjects is much wider than the subjects of rule-making, which confirms the position that law-making is a more generalized, broad concept than rule-making, the circle of subjects of which is limited by central executive bodies. The characteristic features of acts of central executive bodies include the following: these are the rules of conduct of central executive bodies; this behaviour is aimed at complying with regulations; expressed in a certain legal document; the issuance of such acts is carried out in the process of public administration; they are issued by authorized state bodies or their officials; the direction of their action can be both general and individual; they contain norms of legal orientation; they are aimed at achieving a specific result. The classification of types of rule-making activity of central executive bodies according to the following criteria is offered: depending on the level of the subject of rule-making; depending on the type of legal act that is created (classic rule-making process and additional-conditional rule-making process). The factors that determine the need to reform the rule-making activities of the central executive bodies of Ukraine are identified. The ratio of law-making and rule-making activities of central executive bodies is carried out. The blocks of the rule-making process of the central executive bodies are distinguished.

The Concept of administrative reform in Ukraine is characterized as a basis 


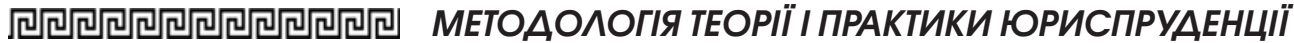

for reforming the normative central activity of executive bodies in Ukraine. The features and types of bylaws of central executive bodies have been clarified. Proposals and recommendations for improving the legal regulation of rule-making activities of central executive bodies are provided.

Key words: executive power, ministry, normative legal act, normative activity, powers, legal regulation, public administration, central executive body.

\section{Література}

1. Юридична енииклопедія : в $6 \mathrm{~m}$. m. 4 : Н - П / НАН України. Ін-т держави і права імені В.М. Корецького ; голова редкол. Ю.С. Шемшученко ; редкол.: М.П. Зяблюк, В.П. Горбатенко : «Вид-во Українська енциклопедія» імені М. П. Бажана, 2002. 720 с.

2. Сучасна правова енциклопедія / О.В. Зайчук. Київ : Юринком Інтер, 2015. 408 c.

3. Расюк А.О. Відомча нормотворча діяльність в Україні та шляхи ї модернізації. Наука $і$ правоохорона. 2019. № 1. С. 140-147.

4. Чабур С. Поняття, роль та методи лобізму у правотворчому проueci. Europsky politicky a prauni diskurz. 2018. Vol. 5, Iss. 1. C. 111-116.

5. Тарахонич T.I. Громадська думка: поняття, особливості та місце в правотворчому процесі. Правова держава. 2020. Bun. 3. C. 62-71.

6. Наджафгулиев Р.И. Теоретические и практические аспекты правотворческой деятельности парламента в обеспечении прав и свобод беженцев и вынужденных переселенцев на примере Азербайджанской Республики. Правовий часопис Донбасу. 2020. № 3. С. 38-46.
7. Шапран Ю.В. Удосконалення механізмів захисту прав людини крізь призму сучасної правотворчої політики в Україні. Альманах права. 2020. Bun. 11. С. 265-269.

8. Жидецьька В.В. Стадії нормотворчого провадження міністерств в Україні. Держава і право. Серія : Юридичні науки. 2016. Bun. 74. C. 49-58.

9. Левченко М.В. Контроль та нагляд за правотворчістю суб'єктів владних повноважень: постановка проблеми. Бюлетень Мін'юсту України. 2019. № 12. C. 48-52.

10. Чаплюк O.I. Співвідношення суб'єктів національної та міжнародної правотворчості: методологічні аспекти. Часопис Київького університету права. 2015. № 2. C. 36-39.

11. Чабур С.В. Види правотворчості за суб'єктним критерієм. Правова держава. 2017. № 25. С. 32-38.

12. Ващенко А.М. Правотворча діяльність органів $і$ посадових осіб держави та місцевого самоврядування: проблеми $i$ перспективи наукового пізнання. Альманах права. 2017. Bun. 8. C. 134-138.

13. Про заходи щодо вдосконалення нормотворчої діяльності органів виконавчої влади : Указ Президента України від 9 лютого 1999 р. № 145/99. URL : http: / / www.zakon4.rada.gov.ua.

14. Рябченко T.О. Форми безпосередньої участі громадян у правотворчості. Правові горизонти. 2016. № 1. С. 7-15.

15. Лепех Ю. Питання про співвідношення понять «правотворчість» та «нормотворчість». Вісник Національного університету «Львівська політехніка». Юридичні науки. 2016. № 855. С. 225-231.

16. Ничка Ю. Підзаконна правотворчість: загальнотеоретична характеристика. Вісник Львівського університету. Серія юридична. 2015. Bun. 61. C. 45-49. 